\title{
9 A Contested Jurisdiction: Armenia in Late Antiquity
}

Tim Greenwood

Although Roman and Persian engagement with late antique Armenia has been analysed from several perspectives, its juridical dimension has been largely ignored. This chapter provides a reassessment of the legislation pertaining to Roman Armenia from the reign of Justinian, arguing that it offers a reflection of legal practices operating beyond the newly reorganised Roman provinces, in districts of Armenia under Persian hegemony. It may also attest the seeping of Roman legal culture beyond the formal limits of the jurisdiction. Crucially, the local inheritance practices which the legislation prescribes find analogues in Sasanian jurisprudence. Although not every aspect of Persian legal culture will have been replicated in the districts of Armenia or received in the same way, the rich Armenian literary tradition from late antiquity reveals a proximate legal culture, expressed in terms of concepts employed and processes followed. Three illustrations from Lazar P'arpets'i History are examined. Furthermore two later compilations preserve valuable evidence of law in practice. The tenth-century compilation titled History of Atuank' contains a collection of documents deriving from the Council of Partav convened in $705 \mathrm{CE}$. One of these confirms that land across Caucasian Albania was still being bought and sold at this time, that there was current uncertainty over whether the transfer of a village included the village church and its endowment, and that laymen had been represented as holding clerical status to circumvent this. A specific case is then outlined. The late thirteenth-century History of Siwnik' on the other hand contains transcripts of fifty-two documents, and summaries of twelve more, recording property transactions in favour of the bishops of Siwnik' and the see of Tat'ev. It is argued that the earliest of these, dating from the middle of the ninth century, preserve clear vestiges 
of Sasanian legal culture. Armenian sources have much to tell us about law and legal tradition in Sasanian Persia.

Armenia was wholly partitioned between the 'great powers' of Rome and Persia throughout late antiquity. Although the manner and the degree of intrusion on the part of the two imperial powers may have fluctuated over the course of the two centuries following the eclipse of the Arsacid kingdom in $428 \mathrm{CE}$, every district of Armenia was under the hegemony of one or the other. There was no neutral space, no gap between them into which an independent Armenia might be squeezed. We need to be reminded of this because the rich Armenian literary tradition frequently projects an alternative landscape, an Armenia comprising a single people united around a single confession of faith, inhabiting their own land and relating to those same powers of Rome and Persia in the manner of a sovereign nation. Although this singular construction exercised a powerful influence on Armenian historical memory - and continues to do so today - it obscured a very different reality. Not only was late antique Armenia plural, contradictory and volatile, a world of rival local lordships, of different expressions of Christian doctrine, practice and cult, of multiple historical traditions, even of different forms of spoken Armenian; by virtue of its partition, it was also exposed to Roman and Persian systems of government and administration. ${ }^{\mathrm{I}}$ The regions of historic Armenia encountered and responded to the evolving institutions and practices of both empires on an individual basis. For much of the fifth and sixth centuries, approximately four-fifths of historic Armenia fell under Persian control, with only those districts to the west of the upper Euphrates fully incorporated into Roman provincial structures. From the last quarter of the sixth century, however, the balance of power across Armenia fluctuated, as a result of both negotiated settlements and military action, and this unstable state of affairs persisted until the first Arab raiders crossed into Armenia from the Jazira in autumn 640. Armenian reception of imperial traditions, therefore, was far from a straightforward or singular process.

Several aspects of Roman and Persian engagement with late antique Armenia have been traced in previous scholarship. ${ }^{2}$ The heroic resistance led by Vardan Mamikonean to the imposition of Zoroastrian practices and beliefs by an impious Persian shahanshah, Yazdgerd II, which culminated in defeat at the battle of Avarayr in 45 I CE, quickly became central to Christian Armenian memory and tradition. This episode, together with the conversion of King Trdat 
by Grigor the Illuminator at the start of the fourth century, has been studied repeatedly. We should recall, however, that Garsoïan's meticulous examination of the Armenian church in late antiquity also reveals the intrusion of dyophysite challenges from east and west in the course of the fifth, sixth and early seventh centuries; there was much more to Armenian Christianity than Grigor, Trdat and Vardan, significant though they were. ${ }^{3}$ Research has also been conducted into how members of the elite were drawn into closer relationship with the great powers, through the award of titles, offices and gifts, and how this enabled Armenian military manpower to be exploited for service on distant frontiers. ${ }^{4}$ Finally, there has been some study of the respective provincial structures which overlaid the districts of Armenia, and in particular how the Roman network changed over time; there has been less work on how the Sasanian administration evolved, although there is strong evidence to indicate that it did. ${ }^{5}$ To date, however, there has been little in the way of sustained investigation into Armenian jurisprudence and the legal culture, or cultures, which operated across Armenia in late antiquity. Yet since Armenia was wholly partitioned between Rome and Persia in late antiquity, we need to consider the extent to which these twin powers introduced their own legal and judicial traditions, to what purposes and with what results. Late antique Armenia was not only the locus for military, social and cultural competition between the great powers; as we shall see, it was also contested from a juridical perspective.

Let us start by examining the situation of those districts of Armenia under Roman control. Adontz demonstrated in his magisterial study that the provincial reorganisation undertaken at the start of the reign of Justinian was intended to transform the districts of Roman Armenia. ${ }^{6}$ For our purposes, it is highly significant that the three pieces of relevant legislation describe both the circumstances prevailing at the time and the new structures, processes and principles being instituted. All three therefore offer an impression of the present state of affairs and a vision of the future.

The first of the three is Novella XXXI, dated I 8 March $536 \mathrm{CE}$ and addressed to John, most honoured praetorian prefect of the east, second among the bypatoi and patrikioi. This Novella created four new provinces of Armenia. They extended over districts which had hitherto been treated in different ways by the Roman state. The new province of Fourth Armenia, for example, covered land which had not previously been included in the network of provinces 
but had been settled by various nations, bearing different barbarian names: Tzophanene and Anzitene and Tzophene and Asthianene and Balabitene, under satraps; the name of such a ruler was neither Roman nor known to our ancestors but had been established by the other politeia. ${ }^{7}$

This can only be referring to Persia, although the failure to identify it openly as a rival source of political authority is significant. Fourth Armenia overlay districts which had hitherto been outside the Roman provincial framework, and hence beyond the purview of Roman law. By way of contrast, the new Second Armenia was created largely, although not exclusively, from the former First Armenia, and the new Third Armenia seems to have mirrored the former Second Armenia. These regions had been incorporated long before into the Roman provincial network and so had been situated within the limits of Roman jurisprudence.

Two features of Novella XXXI merit particular comment. In the first place, the boundaries of three of the four new provinces were defined in terms of cities and their territories. First Armenia had Justinianopolis as its metropolis, together with six other named cities; Second Armenia contained Sebasteia together with four other cities; and Third Armenia included the metropolis of Melitene together with four other cities. By contrast, Fourth Armenia was described in terms of the five satrapies, the city of Martyropolis and the newly constructed fortress of Kitharizon. It was conceptualised therefore in very different terms, as a province without cities. Although Fourth Armenia did contain several historic centres of settlement, such as Angł, which might have qualified as cities, these were left out of the definition. But it could be that its lack of urban centres was intended to be a metaphor for its lack of Romanitas, a cultural as much as a sociological comment. As Maas has noted, the intended audience for the Novellae was Roman, both in Constantinople and in the provinces. ${ }^{8}$ Secondly, the juridical status of each province was established unequivocally. The governors of First Armenia and Third Armenia were defined as spectabiles, the former under the most magnificent anthypatos, Acacius, the latter under the Justinianic count, Thomas. The governors of Second Armenia and Fourth Armenia, however, were ordinarii. Appeals from Second Armenia in cases worth up to five hundred solidi went up to the anthypatos in Justinianopolis for final adjudication; appeals from Fourth Armenia in cases with the same limit went up to the Justinianic count in Melitene for final adjudication. ${ }^{9}$ Although no evidence of this appellate system survives, these provisions confirm that Roman law was intended to operate across 
all four provinces, that there was, at least in principle, no space for the continuing operation of existing traditions. ${ }^{\circ}$

The second of the legal instruments, Novella XXI, came into force on the same day as Novella XXXI, I 8 March 536, and was addressed to the most magnificent Acacius, anthypatos of Armenia. It was titled 'Concerning the Armenians, that they should follow the laws of the Romans in everything' and confirmed that there should be no laws among them apart from those which the Romans enacted. ${ }^{\text {II }}$ Roman law was therefore to be exclusive. Two specific practices were highlighted and repudiated: first, that 'inheritance from parents, brothers and other relatives should no longer be to men alone and never to women, a barbaric custom', but should be equal in all cases, the same for women as for men; and second, that women should not be married without dowries. Although the nature of the assets transferred by inheritance are not described in the prologue, the second chapter of the Novella, confirming that the legislation was to come into force from the start of the present fourteenth indiction, stipulated that women should not be treated as sharers in patrimonial estates already divided or inheritances which had taken place in or before the thirteenth indiction.

It has long been recognised that through this legislation, Justinian was trying to subvert customary Armenian inheritance practices and undermine the power of the noble families by precipitating the breakup of the family landholdings. But there are two other features of this enactment which hold particular significance for this chapter. In the first place, the prologue acknowledges that 'this extreme barbarism has been performed among them up to the present day'. This implies a precise knowledge of current inheritance traditions among the Armenian elite, including those newly located within the Roman provincial framework. The prologue goes on to observe that these very harsh customs were not limited to them but 'that other nations acted in a similarly disdainful manner towards nature and had insulted the female sex as if it were not created by God'. The most natural interpretation of this phrase 'other nations' is that it refers to other Armenian princely houses presently situated outside Roman control, in districts of Armenia under Persian control. If they had been located inside the Roman Empire, they would have been subject to Roman laws on inheritance and dowries. That these nations were represented as persisting in their traditions indicates that they were located beyond the present reach of Roman law. Therefore this Novella not only reflects the input of someone conversant with present legal traditions, in all likelihood one of the 
members of the Armenian elite; it also sketches in pejorative terms the encounter between Roman and Persian jurisprudence, for, as noted above, there was no separate Armenian 'space' between the two imperial powers.

The third of the legal regulations comprises an edict or decree preserved in the Codex Justinianus, titled 'Concerning the Order of Inheritance of the Armenians' and dated in one manuscript to I August $535 .{ }^{\mathrm{I} 2}$ In content, there is a considerable overlap with Novella XXI, save in one key respect. The edict prescribed that its provisions were to have retrospective force, being effective from the accession of Justinian. The Novella, however, provides that its regulations were to be effective from the present fourteenth indiction. As Adontz noted, there can be no doubt that the edict predated, and was partly superseded by, Novella XXI. ${ }^{\mathrm{I} 3}$ Nevertheless its provisions merit consideration. The prologue reads as follows: 'We want the Armenians to be delivered from their former injustices, to transfer them to our laws in everything and to give to them fitting equality.' The first chapter continues:

When we learned recently about a certain barbarous and harsh law among them, appropriate neither for Romans nor for the proper justice of our politeia, insomuch as men may inherit from their fathers but never women, for this reason we decree through the promulgating of this divine law, to your Magnificence, that succession is to be equal and concerning those matters arranged in the laws of the Romans concerning men and women, all are to prevail in Armenia; for it is on account of this that our laws have been sent down there, for the administering of them.

The final substantive section reads:

We decree that women shall share in the declared patrimonial estates from the said date. If nevertheless it happens that certain ones are discovered, those who have written all the same that their daughters are to inherit, those who are not included in the intestate succession, then they, and the children born from them, shall have a share in the inheritance of the patrimonial things.

The edict contains several intriguing features. It is not clear exactly to whom it was addressed, although Adontz's suggestion that it was the praetorian prefect of the east, John, rather than Acacius or Thomas, seems more likely. The circumstances in which it was promulgated are not recorded, although the opening words, 'When we learned recently', imply that a concrete case involving a conflict of law had reached the emperor. ${ }^{\mathrm{I}}{ }^{4}$ The issue of what is meant by Armenia and the Armenians is harder to determine. Accepting that it dates from before the full provincial reorganisation described 
in Novella XXXI, it seems improbable that it was directed specifically to the districts of Armenia Minor, Lesser Armenia, since these had been divided into the old provinces of First and Second Armenia in the later fourth century under Theodosius I and so had experienced Roman legal tradition for the past century and a half. Having excluded Armenia Minor, we are left with Armenia Magna, Greater Armenia, sometimes called Interior Armenia, that part of the Arsacid kingdom which fell under Roman hegemony in c. $387 \mathrm{CE}$ and which was governed by the Comes Armeniae, or the five satrapies, discussed above. It is unlikely that this issue will be resolved because aspects of the edict seem to point in opposite directions. On the one hand, the tone of the edict implies the recent despatch of Roman law, suggesting it had not been available and accessible previously; this supports the argument that the edict was drafted with the satrapies in mind. On the other hand, the final sentence of the edict, cited above, clearly envisages that some members of the elite had already tried to write testaments leaving a share of their patrimony to their daughters, in contravention of the prevailing custom of intestate succession which was limited to male heirs. This might seem to favour the identification of Interior Armenia, but it is conceivable that some in the satrapies had already begun to adopt practices of Roman law, including the making of a written will disposing of their assets as they wished, before the districts had been incorporated as Fourth Armenia. If so, this would be evidence for the seeping of Roman legal practice beyond the formal limits of Roman jurisdiction. In any event, whether the edict was intended to operate across Interior Armenia, or the satrapies, or both, the situation was short-lived. Within a year, the two Novellae had transformed the provincial structure and Roman jurisprudence was established as the only competent authority, at least from a Roman perspective. With regret, lack of evidence prevents us from seeing how these changes were implemented, or how they were received or negotiated.

From the above, it is clear that these local inheritance practices had been followed in the satrapies and perhaps in Interior Armenia for generations, in all likelihood since the end of the fourth century. To what extent they were 'Armenian', however, is less certain. It was suggested above that the 'other nations' who followed these traditions were Armenian noble families settled beyond the frontier in Persian-controlled Armenia. The persistence of these traditions may reflect a light-touch approach to provincial administration on the part of the Persian authorities, similar to the manner in which the satrapies had been treated. But it could reflect a different dynamic, 
one which found a much closer correspondence between Armenian and Persian legal traditions. Could it be that Armenian legal culture in late antiquity was closely aligned to Persian jurisprudence?

If we examine once again the four principles and practices picked out for specific criticism in the Justinianic legislation - inheritance restricted to men from their fathers and never women; the notion of the patrimonial or family estate; a system of intestate succession as the norm; and the lack of a dowry - we find close parallels in Sasanian jurisprudence. Macuch has proposed that only a freeborn man above the age of fifteen who was a subject of the shahanshah and a citizen of Eranshahr, confessing Zoroastrianism and belonging to a noble family, had full legal capacity. ${ }^{15}$ A legitimate son stood in direct succession to his father and was heir not only to his property but also to his name and genealogical status, his standing in the community and his rank, gah, in society. Conversely a woman never gained full legal capacity, remaining under the legal guardianship of her father, brother, uncle or other male relative who became the family guardian, and then under the guardianship of her husband after marriage. Although there were certain circumstances in which wives and legitimate daughters were entitled to shares of a husband's inheritance, these did not extend to movable and immovable property which had been passed down from the ancestors, abarmand $i$ pidaran. Such property was held by the head of a household, kadagxwaday, as xwastagdar, possessor of the estate as heir, but it could also be held on the same terms by those to whom a kadag-xwaday had bequeathed property. Crucially, all such property was held as pad abarmand, as an undivided inheritance, and shares in it remained notional. This meant that ancestral family property was held jointly by the possessors. Its substance, bun, was inalienable; its fruit, bar, or income, wax ̌s, could, however, be disposed. In some respects at least, this corresponds to the modern distinction in English law between a legal and an equitable interest. Although Sasanian law recognised other categories of property which could be acquired, held and disposed of in various ways, the substance of ancestral property was, at least in principle, incapable of alienation, displacement or partition by any means and thereby sealed in perpetuity. This ensured the pre-eminence of an elite comprising a small number of families across very long periods of time. And this seems to be precisely the challenge which confronted Justinian and his legal officers along the eastern frontier, in the satrapies and possibly Armenia Interior, and against which the legislation was drafted.

Yet we should be cautious before accepting that every aspect of 
Sasanian jurisprudence was present across the districts of Roman Armenia throughout late antiquity. The satraps and the otherwise anonymous elite of Armenia Interior were neither subjects of the shahanshah, nor citizens of Eranshahr, nor, so far as we know, practising Zoroastrians. Conversion to Christianity should have put an end to the complex regulations permitting several different forms of marriage as well as incestuous relationships, all devised to perpetuate a nobleman's lineage. ${ }^{16}$ On the other hand, one could certainly envisage a world which was Christianised rather than Christian, loosely integrated into state and ecclesiastical institutions, where traditional practices in relation to inheritance and family property persisted across the generations, even if consanguineous and multiple marriages to ensure succession disappeared. We have seen from the above discussion that notions of ancestral property persisted, and in circumstances where traditional inheritance mechanisms were effective and trusted by the elite, there would have been little impetus for change. So it is possible, even likely, that the legal culture in Roman Armenia was extremely conservative and, outside the original provinces of First and Second Armenia, underwent little change between the late fourth century and the first years of Justinian. If, however, we accept this, it follows that the specific elements referred to in the legislation and analysed above need not be 'Sasanian'. Rather they may reflect even deeper traditions, going back into the Parthian era. It is conceivable therefore that the Justinianic legislation contains a reflection of Parthian jurisprudence.

Let us turn to consider the juridical situation of those districts of Armenia under Persian hegemony, known to Roman contemporaries as Persarmenia. We know that by the sixth and seventh centuries, Sasanian law was, in the words of Macuch, 'by no means less sophisticated than Roman law of the Byzantine era' ${ }^{17}$ There are tantalising references to a large number of works on jurisprudence and commentaries on a range of subjects compiled by legal scholars. We can be confident that there were very many court archives, containing a mass of records of other documents, as well as private archives, holding the legal documents pertaining to individual noble families. There does not appear to have been any systematic treatment of Sasanian law to compare with either the Theodosian Code or Justinian's Corpus iuris civilis, but that may be more to do with the vagaries of preservation than anything else. For with the exception of the single seventh-century Sasanian law book, Hazar Dadestan, no substantial compilation of Sasanian legal literature survives. ${ }^{18}$ Therefore it is not possible to turn to collections 
of normative statements of Sasanian law and presume that these applied to Persarmenia. Nor, with regret, can we turn to a contemporary Armenian collection, for such a work has not survived, if indeed it ever existed in the first place. Nevertheless this is not quite the end of the trail.

In the first place, there are numerous references in the surviving Armenian literature which attest a proximate legal culture. If we limit ourselves to the History of Łazar P'arpets'i, a work assembled at the very start of the sixth century, we find three significant passages. At the start of book I, King Arshak is described as 'abandoning and deserting the fortunate and original inheritance of his ancestors', zbari ew zbnik zharangut 'iwn naxneats' iwrots' ${ }^{\text {'19 }}$ Examining the transliterated forms, it seems more likely that this recorded his abandonment of the bar and the bun, both the fruit and the substance, of his ancestral inheritance. In other words, he repudiated his full entitlement for ever, extinguishing his own rights and those of his family in perpetuity. This original meaning, however, was lost, either at the time of composition or in the course of transmission - the earliest manuscript to preserve Lazar's History is M2639, dated I672 CE - when the transliterated Middle Persian loanwords were modified. ${ }^{20}$ Whilst bnik retained something of the sense of bun, albeit in adjectival form, the addition of an ini to bar brought about a significant shift in meaning. The second passage implies that legitimate adult daughters did not have full legal capacity. It records that 'the man of God Sahak gave and sealed the possessions of his villages and estates', et ew knk'eats'surb ayrn Astutsoy Sahak zstats'uatss geawtits' iwrots' ew agarakats', to the three sons of his daughter because he did not have a son; 'he gave to them and to their offspring as an inheritance for ever', et nots' $a i$ zharangut'iwn ew zawaki nots'a minch'ew ts'yawitean. ${ }^{2 \mathrm{~T}}$ It appears that his daughter was not legally competent to inherit. Rather than follow Sasanian legal practice and Zoroastrian tradition in creating a legal male heir, Sahak transferred his property to his three grandsons. And finally, when setting out his demands to the messengers of Nixor Vshnaspdat, Vahan Mamikonean requests that 'you allow us our patrimonial and original religion', zhayreni ew zbnik orēns mer $i$ mez t'oluk'. ${ }^{22}$ This is a striking phrase, applying bun, the formal term for the substance or full legal title of a material property, possession or asset, to an immaterial, spiritual asset, in the form of Christian belief. Thus when Łazar represented Vahan making this request, he was employing meaningful legal terminology, asserting that Christianity was an inalienable possession of the 
Armenian people. Evidently the technical sense of bun still held meaning at the start of the sixth century. As Thomson notes, it had also held meaning to the author of the Buzandaran, writing in the 48 os, but looking back to the events of the fourth century. Thomson further observes that by the time Ełishē was composing his History, perhaps in the 570s, the term bnik was no longer in use; the same sense could be conveyed through the use of the term hayreni. ${ }^{23}$ This suggests that legal terminology was not static and that within his History, Ełishe was reflecting these changed circumstances.

Łazar's so-called Defence, a separate letter sent by him from exile in the city of Amida, and appended to his History in M2639, also offers insight into contemporary legal practice. In response to the accusations that he had abused his position when serving as abbot, Łazar observes that 'three brothers loved the monastic community of the Holy Cathedral with fruits and all necessities' and that 'the gift of each of them was known and set down in writing in the place', orots' iwrak' 'anch 'iw' uruk' turn yaytni èr ew grov mnats' $i$ tetwojn. ${ }^{24}$ Elsewhere he notes that 'the things I brought from Ałuank' and Virk' and Siwnik' and Arsharunik', and the things from the nephews of your Lordship, each gift was set down separately in the place'. ${ }^{25}$ These incidental remarks indicate that every gift to the community was set down in writing, that the monastery had its own archive recording both the donors and their gifts. No such archive survives; the closest we can get is to interpret a small corpus of Armenian building inscriptions on these terms, as records of the donation and the identity of the donor(s) on the endowment itself. ${ }^{26}$

It follows therefore that traces of Armenian legal culture are reflected in Łazar's History, and careful analysis of other late antique texts - notably the Buzandaran and Etishē's History, referred to previously, and the Girk' T'tt'ots', Book of Letters, a collection of ecclesiastical correspondence assembled at the start of the seventh century - reveals other instances which cannot be discussed here for reasons of space. ${ }^{27}$ These traces appear to correspond to features of Sasanian law. We have to look elsewhere, however, for more substantial evidence of this legal culture. Fortunately two later compilations preserve such material.

The first body of evidence is preserved in a collection of documents recording the circumstances and the decisions of a council of the church of Aluank'held at Partav in 705 CE and preserved in a composite work assembled in the tenth century, titled History of Atuank $:{ }^{28}$ Beyond observing that there is no reason to question the authenticity of this bundle of documents, the details of the whole 
council do not concern us here. The final document in the collection, however, merits close attention. It is described as an ordinance, established by Simeon, the newly-installed catholicos of Ałuank'. Simeon expresses a general determination to reform the institutions of the church, but identifies one abuse in particular. According to Simeon, unworthy men and soldiers had been gaining possession of church property: 'No one shall have authority to entrust a church of God to unworthy men or soldiers, nor to sell it, as if a possession, nor to give it to princes or to their tutors as a gift. ${ }^{29}$ Furthermore Simeon asserts that 'the churches of God are free [azat] and under the authority of no one other than bishops and those to whom they have given the churches, that is to say, chaste and true holy priests and not unworthy soldiers'. ${ }^{30}$ He continues, 'Today, all the laymen have this rule, that when they sell their own villages [zgiwts iwreants sephakans], they write the deed [zktakn] in this way, "apart from the church and the soil of the church"'.3 ${ }^{31}$ ince we lack contemporary documents recording property transfers, either in the districts of Ałuank' or in Armenia, it is impossible to know whether Simeon was trying to introduce this condition into all future transactions or was reflecting current practice. Nor can we judge how effective it was. In any event, he notes, 'I hear grumbling from many people, that in many places, soldiers are taking possession of the churches of God through the status of being an abbot. ${ }^{32}$ Not only were churches and church assets being transferred to soldiers; by asserting that they held the status of abbot, they were also employing a legal fiction to secure those assets.

This ordinance therefore attests several features of legal practice. It confirms that at the start of the eighth century, villages were still being bought and sold by laymen in Ałuank' and that title was transferred by written instrument. Evidently there was some uncertainty as to whether the transfer of such properties included or excluded the church in the village and its endowment. Simeon was at pains to stress that it did not, that title to churches and church assets were vested in the bishop and could only be transferred to priests. Whether this had always been the case is hard to tell but the widespread use of the fiction, whereby laymen were represented as having clerical status to enable them to take possession of churches and their endowments, suggests that church property had been regarded as separate from other categories of property for some time before 705 CE.

The ordinance contains one further surprise. In its conclusion, Simeon sets out a brief summary of a recent property dispute: 
Concerning which as well K'shik abbot of Nersmihr, brought up in holiness and tanuter of the monastery, has written that Varaz Trdat, prince of Ałuank', gave this very small village of Holy Cross for service for the sake of his soul. Now a cavalryman, P'usan Veh by name, a layman, who has lived in debauchery, presents documents that 'the prince of Ałuank' gave that church to me through the office of abbot because of my tutorship'. With regard to that, $\mathrm{O}$ beloved ones, this law shall exist from now on for the future: it shall not be for P'usan Veh to hold that church in accordance with the command of the Holy Spirit; but unsullied and pure priests shall have control over the church, because that man does not have authority from God or from us. ${ }^{33}$

$\mathrm{K}^{\prime}$ 'shik was not an obscure individual. He appears as a signatory to the undertaking signed by both clerics and laymen of Ałuank' at the council of Partav by which they repudiated Nersēs Bakur and were reconciled to the Armenian church under its catholicos Ełia. He was the first named of several abbots after Simeon and four other bishops, implying that he was a leading cleric at the time. ${ }^{34}$ Furthermore, K'shik was one of two abbots with whom Ełia deposited a signed and sealed document confirming that he had received the undertaking. ${ }^{35}$ The location of the monastery of Nersmihr is unknown but it was evidently a prominent community. As well as being entrusted with the safe-keeping of such important documents, the above confirms that the community had been endowed by the prince of Ałuank', Varaz Trdat. The figure of P'usan Veh is also unknown. Evidently he too had enjoyed close ties to a prince of Ałuank', conceivably the same Varaz Trdat. The reference to Varaz Trdat supplies a secure historical context. He was the nephew of Prince Juanshēr and succeeded the latter as prince of Ałuank' after Juanshēr's murder in September 669 CE. Varaz Trdat seems to have held power until c. 699, when he was imprisoned by the emperor Justinian II in Constantinople. It was during his five-year absence that Nersēs Bakur induced, or worked in concert with, Spram, the wife of Varaz Trdat, to introduce dyophysite teachings into Ałuank', prompting the intervention of Ełia and the council of Partav. ${ }^{36}$

Two striking features merit comment. The first is that we find Simeon exercising judicial authority, preferring the suit of $K^{\text {'s }}$ shik to that of P'usan Veh, despite the latter presenting documents before him. This corresponds to the legal identity and self-determination granted to other religious communities within the Sasanian Empire, arrangements which persisted after its demise. The second is that

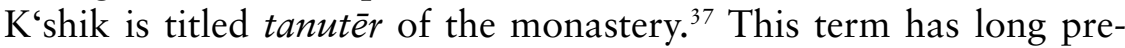
sented a challenge to historians. Although its meaning has always been clear enough, 'lord of the house', its apparent overlap with other social terms, including têr, naxarar and others, has always remained 
something of a mystery. Yet if we treat it as an Armenian calque on the Middle Persian kadag-xwaday, master of the household or pater familias, its true meaning becomes clear. It is used to describe someone's legal status, someone in whom the inalienable property of the family, whether genealogical or spiritual, was vested.

It is clear from the above that the country of Ałuank' possessed a sophisticated legal culture at the start of the eighth century. From where did it come? The most straightforward solution is to propose that it reflected pre-conquest Sasanian legal principles, practices and language, that legal process in Ałuank' in the century after the conquest, at least with respect to property transactions, was closely related to legal process before the conquest. The traditional mechanisms for transferring property continued to be used because all parties to a transaction trusted in their efficacy. Even the endowment by Varaz Trdat of a small village to the monastery of Nersmihr for the sake of his soul had a clear parallel in Sasanian law, albeit in a Zoroastrian rather than a Christian context; 'property of the soul', xwastag $i$ ruwan, was intended to provide income for rites and ceremonies to be performed after a person's death. Admittedly there are some aspects which are unclear. Had the catholicos always been involved in adjudicating disputes or was this a development of the post-conquest era, or perhaps even a temporary state of affairs following the detention of Varaz Trdat in the Byzantine Empire? Should we treat the repeated references to soldiers and cavalrymen obtaining church property as evidence of recent political turmoil - perhaps linked to Khazar raids and Umayyad counter-offensives from $685 \mathrm{CE}$ - or, in the alternative, increasing confidence on the part of the catholicos Simeon to protect the interests of the church against familiar abuses? These questions may never be resolved. That the legal culture pervading Caucasian Albania at the start of the eighth century was strongly informed by Sasanian tradition is, however, evident.

We must advance to consider the second compilation. The History of the Province of Siwnik' was assembled by the metropolitan bishop of Siwnik', Step'anos Orbelean, in I 299 CE. It treats the whole of Siwnian history from its mythical origins to the year of completion, drawing upon a wealth of written sources going back centuries, including ecclesiastical correspondence, theological treatises and a large number of documents recording property transactions in favour of the bishops of Siwnik' and the monastery and churches of Tat'ev where they were based. Indeed, it preserves the full text of no fewer than fifty-two such deeds, together with summaries of, or substantial 
extracts from, a further twelve documents. The earliest is dated to the year 288 of the Armenian era (30 April 839-29 April 840 CE). ${ }^{38}$ They are distributed unevenly across time, with twenty-four dating to the period between 839 and 945 but none at all between ro89 and I223. Step'anos does not reveal exactly where he found them, but he admits that one of the original deeds was so old and worn around the edges that it was only possible to read some of the words and 'on account of its length we reckoned it would be tedious to our audience and so we have not included it'. ${ }^{39}$ Evidently he had access to the actual documents, some of which were in poor condition. Furthermore it is significant that the charters incorporated by Step'anos tend to appear in clusters within his composition, in small groups of three or four. They repeatedly disrupt the narrative and the chronological progression of the text. One of the clusters, of three late ninth-century conveyances, moves backwards in time. ${ }^{4 \circ}$ Arguably this reflects the sequence that he found them in, indicating that they were stored in a bundle with the oldest at the bottom. In this one instance, picking them off the pile in front of him, he forgot to reverse the sequence. There seems little doubt therefore that Step'anos exploited the episcopal archives when assembling his History, and that these contained bundles of documents recording endowments, just as Łazar P'arpets' $i$ had described.

The earliest cluster comprises four charters which record villages being bought, exchanged and given to the see. The following is a translation of one of them:

In two hundred and ninety-three of the Armenian calendar [29 April 844-28 April 845], a wish came upon me, P'ilippē, son of Vasak, lord of Siwnik'. I gave Tat'ev for the sake of my soul to you, lord Davit', bishop of Siwnik', which had arrived in my inheritance from my father anxuēš k'arē with all its boundaries, mountain and plain, vines and walnut trees, water-meadows and mill, and whatever are its entire boundaries. And may no one dare after my passing, my sons or my brothers or descendants, to remove that village from that church and that Holy Cross; otherwise may he be condemned by God and by that holy church and by that Holy Cross and may he endure curses from that spiritual lord. And I have given with open heart and mind to you, lord Davit', bishop of Siwnik', to enjoy throughout a peaceful lifetime, and those others who succeed after you to that see, may they enjoy until the coming of Christ. If they remain, may they exist in that way; but if they go, may they not dare to remove that village with its definition from that church, or to sell, or to exchange, or to establish as security [gravakan dnel]; but those who are servants of the church shall be master [ǐsxan] of all the boundaries. And the witnesses shall be the God-protected lord [têr] Grigor, lord of Siwnik', lord Atrenerseh son of Vasak, lord of Siwnik', lord Grigor, son of Sahak, lord Hrahat and lord Aruman, sons of Sahak, lord Hrahat and lord 
Gagik, sons of Grigor lord of Siwnik‘ ... [and a further twenty-eight named lay figures and clerics] And for the sake of further confirmation, I have set my customary seal and those of my sons and the other nobles. ${ }^{4 \mathrm{I}}$

This deed gives important insights into the prevailing legal culture in mid-ninth-century Siwnik'. It retains two phrases which are transliterations of Middle Persian: anxuēš k'arē, a seemingly garbled form which must be related to xwēših, ownership with the right to dispose of the property, and which speaks to the nature of the rights conveyed to lord P'ilippe from his father; and gravakan, in Middle Persian grawgan, a form of mortgage giving the creditor access to the increase, bar, of the property, until the loan was repaid. ${ }^{42}$ It is highly likely that these phrases were vestigial by the time this deed was executed, carried over from earlier documentation but retained nevertheless. Legal instruments tend to possess an inherent conservatism in form and language - even to the point of retaining elements which no longer function or reflect the present circumstances - for as long as all parties believe that they are effective in fulfilling their intentions. The deed contains other formulaic phrasing in the generic description of the property being transferred and in the range of transactions prohibited once the transfer has been performed. These lists imply an underlying legal culture of sophistication, one that was capable of envisaging and prescribing various dealings in the future. The statement that the transaction occurred through the wish of the donor is also significant because this was a necessary element of a binding contract under Sasanian law. Moreover, in expressing anxiety that his sons, brothers or descendants might try to disrupt or overturn his endowment, Lord P'ilippē appears to deny agency to any female relative, a feature we have observed previously.

In its terminology, formulae and legal principles, therefore, this deed reflects late antique Sasanian legal culture. It is not the only example. All four of the documents in the earliest cluster do so. The oldest document describes the purchase of the village of Artsiv in similar, though not identical, terms to those seen previously, 'with its boundaries, mountain and plain, the arid [zostin] and the watered [zjrarbin] and the pasture [zarawt erkir], field and meadow [zart ew zmarg] '. ${ }^{43}$ Unlike the above, it defines the limits of the property being conveyed in terms of specific local topographical features - named watercourses, valleys, rocks, hills, paths and even 'the field of Vardan' - along its eastern, western and southern boundaries respectively. ${ }^{44}$ Another of the four refers to the grawgan form of mortgage. ${ }^{45}$ A deed of exchange dated 320 of the Armenian era (23 April 87I-2I April 872) states that the transaction was in 
accordance with the will of both parties to the transaction: 'And we have undertaken the transfer with both parties willing and in agreement, I and lord Sołomon. ${ }^{46}$ This document also refers to the two villages 'in accordance with its definition and the royal nepak', a word which seems to be a transliteration of the Middle Persian term nipek, meaning document or perhaps list. ${ }^{47}$ This could be referring to a formal record of the property - and perhaps a process of registration - in the provincial archives or diwan. If so, it too would be vestigial, another distant echo of a process followed in late antiquity but long since abandoned. This might seem anomalous: should not all the deeds include such a provision? But we should not expect absolute consistency of expression across all the deeds. They do not derive from a single template. In the absence of a supervening judicial authority, to monitor and regularise, arguably each form of transaction - purchase, sale, exchange, partition, endowment developed its own patterns and nuances, reflecting Sasanian legal culture in its own way.

In support of this remarkable persistence of Sasanian legal tradition, it is worth recalling that Siwnik' was an eastern region of historic Armenia, bordering Ałuank', and never under direct Roman control, even at its greatest extent. It was also a remote highland region, hard to access and difficult to administer, lacking an urban centre through which to transmit alternative legal cultures. Unlike many of the districts of Ałuank' to the east or Armenia to the north and west, it did not experience Arab or Persian settlement in the second half of the eighth century, and was apparently not subjected to a more intensive regime of provincial government. Rather it was left to its own devices, with minimal intrusion or interference. We should not, therefore, be altogether surprised that the oldest documents uncovered and preserved by Step'anos Orbelean retain features of Sasanian legal practice two hundred years after the demise of the last shahanshah. Yet it is also striking that several of these features vanish in the second half of the ninth century. This is accompanied by a greater awareness of Islamic practice and jurisprudence. The expressions halal and haram appear in the deeds, with the former being applied in one instance to the source of a donor's wealth. ${ }^{48}$ Moreover there is a much greater prominence afforded to protective curses, situated at the end of the document and now directed specifically at Christians or Muslims who dare to meddle with the transaction. ${ }^{49}$ These developments may have been responses to the harsh campaigns of Bugha the Elder across the whole of Armenia, including Siwnik', in the mid-850s. ${ }^{5 \circ}$ Alternatively it may be that 
when Mariam, the daughter of Ashot I Bagratuni, settled in Siwnik' as the wife of Vasak, lord of Siwnik', she preferred to use Bagratuni legal traditions for her many foundations and endowments; she was living in Siwnik' by $874 / 5$ and was still active in 903/4. Unfortunately, we have no contemporary legal documents from the Bagratuni-held lands in central Armenia with which to make comparison. Whatever the stimulus, the documents attest an awareness of, and engagement with, the contemporary Islamic legal culture as well as a need for greater spiritual protection - hence the evocation of divine sanction on any Christian or Muslim who contravened the terms. As a result, towards the end of the ninth century, the reflection of Sasanian legal culture in the deeds of the see of Siwnik' began to fade.

Armenia in late antiquity was therefore a site of juridical contestation. The western districts under Roman hegemony after the fourth century experienced different administrative arrangements. Those incorporated into the provincial network fell within the jurisdiction of Roman law; those associated with the Roman Empire by treaty or agreement persisted in their own traditions, which owed much to Persian - and perhaps even Parthian - legal culture. The Justinianic reforms transformed this plural legal landscape, replacing - or more probably overlaying - local traditions with Roman law. Although the intention of the legislation is clear, its reception is harder to discern; no legal documents survive from the four new provinces of Armenia, and we have no sense of local reactions or responses. Conversely several Armenian sources composed in those districts of central and eastern Armenia under Sasanian hegemony attest an ongoing familiarity with contemporary Sasanian legal principles, concepts and terminology. Some terms were absorbed and preserved in transliteration; others were rendered in Armenian translation. Although again no legal records survive, evidently Persarmenia was suffused with Sasanian law. It is only through two later historical compositions that we obtain sustained insight into the reception - and retention - of that law in specific regions. Legal culture in Caucasian Albania at the start of the eighth century continued to be informed by Sasanian practices and traditions. The evidence from the composition of Step'anos Orbelean suggests that the same was true of Siwnik' in the middle of the ninth century, although this was about to change. Extending Garsoïan's thesis of the 'Iranian' index of medieval Armenia, Armenians living under Sasanian rule acknowledged and used Sasanian law, although we cannot be certain how it was received and used in every district in every period. ${ }^{51}$ Nevertheless the Armenian evidence has the potential to reveal as much about 
Sasanian law and the nature of the Sasanian Empire as it does about Armenian experiences within that empire.

\section{NOTES}

I should like to express my sincere thanks to Professor Caroline Humfress for her generous and stimulating comments on an earlier draft. All Greek, Latin and Armenian translations are my own. For the Armenian transcription, I have adopted the system followed in Thomson and Howard-Johnston I999, with one minor revision.

I Step'anos Siwnets'i I970: I87. In his commentary on Dionysius Thrax, this eighth-century scholar identified dialects of Armenian from the districts of Korch'ayk', Tayk', Xoyt', Fourth Armenia, Sper, Siwnik'and Arts'ax.

2 Garsoïan I985; Mahé and Thomson 1997.

3 Garsoïan r999a.

4 Charanis I959: 28-36; Thomson and Howard-Johnson I999: 2, I73-9I; Garsoïan I999b: 53-62.

5 Adontz 1970: 7-I64; Garsoïan 2009. One significant development involved the transfer of the diwan of Siwnik'from Dvin to P'aytakaran 'so that the name of Armenians would no longer be applied to them'; see Sebēos I979: 67-8 (ch. 8). For the experience of other Christian communities within the Sasanian Empire, see now Payne 2015.

6 Adontz I970: 103-64.

7 Nov. Just. 3I.I.

8 Maas 1986: I8-19, 25-7; 1992: 20, 26.

9 Nov. Just. 3I.I.I-3.

Io Humfress 2005: I62, I76-8.

II Maas 2010: 238-9, 292-3.

I 2 Edict III, De Armeniorum Successione, in CJC III.760-I.

I3 Adontz I970: I45.

I4 I am indebted to Professor Humfress for this suggestion.

I 5 Macuch 20 II.

I6 Macuch 2003: 232-3, noting modifications made by Christian communities to family and inheritance law.

I7 Macuch 2004: I82.

I8 Perikhanian I997. See Bakhos and Shayegan 20I0 and Macuch 20I4 for recent research on the Babylonian Talmud and legal pluralism in the Sasanian Empire.

I9 Łazar I904: 9, lines I3-I4 (ch. 7).

20 Thomson I99I: 3.

2I Łazar 1904: 37, lines 2I-7 (ch. I8).

22 Lazar I904: I6I, I 2 (ch. 89).

23 Thomson I991: 28-9.

24 Łazar 1904: 195, I7-I9.

25 Lazar 1904: 196, 2I-4.

26 Greenwood 2004.

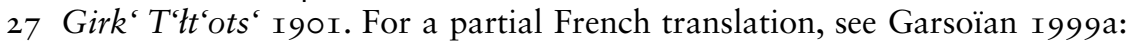
$4 \mathrm{II}-583$. 
28 Movsēs Kałankatuats'i I983: 293.I-3 II.5 (book III, chs. 3-II).

29 Movsēs Kałankatuats'i I983: 308, I7-I9 (book III, ch. I I).

30 Movsēs Kałankatuats'i I 983: 309, 5-7.

3 I Movsēs Kałankatuats'i I 983: 309, 3-5.

32 Movsēs Kałankatuats'i I983: 309, IO-I 2.

33 Movsēs Kałankatuats'i I983: 309, I4-23.

34 Movsēs Kałankatuats'i ı 983: 300, 5-9 (book III, ch. 8).

35 Movsēs Kałankatuats'i I983: 303.20-304.4 (book III, ch.9).

36 Greenwood 2008: 344-6; Movsēs Kałankatuats'i I983: 3 I I.6-3 I 2.7 (book III, ch.I2).

37 Garsoïan r989: 563.

38 Step'anos Orbelean I86I: I49.22-I50.2I (ch. 38 ).

39 Step'anos Orbelean I86I: I67.I8-22 (ch. 4I).

40 Step'anos Orbelean I86I: I 56.I 8-I6I.4 (ch. 39). The three deeds are dated 330 Armenian era (20 April 88I-I9 April 882), 320 Armenian era (23 April 87I-2I April 872) and 3I6 Armenian era (24 April 867-22 April 868) respectively.

4I Step'anos Orbelean I86I: I 5I.I-I 52.9 (ch. 38 ).

42 Macuch 20II: I90, I9I.

43 Step'anos Orbelean I86I: I49.25-6 (ch. 38).

44 Step'anos Orbelean I86I: I49.26-1 50.3 (ch. 38 ).

45 Step'anos Orbelean I86I: I 53.13 (ch. 38 ).

46 Step'anos Orbelean I86I: I 58.23-4 (ch. 39).

47 Step'anos Orbelean I86I: I 59.I6-I8 (ch. 39): 'We have received Bex in accordance with its definition and royal nepak and we have given Aruk's in accordance with its definition and the royal nepak, which was twelve drams.'

48 Step'anos Orbelean I86I: I70.I7 (ch. 42): 'may the halal become haram', halaln haram etits'i. See also I 57.I 5 (ch. 39): 'from my own halal labours', $i$ halal vastakots' imots'. This appears in a deed dated 330 Armenian era (20 April 88I-I9 April 882).

49 These later developments lie outside the remit of this chapter and merit separate treatment. The earliest sanction clause to protect from violations by Christians and Muslims appears in a deed dated 320 Armenian era $(23$ April 87I-2I April 872): 'And from now on, may no one dare to oppose this inviolable deed [anxaxt vchris], whether one of ours or a stranger. But if anyone attempts this, may he not be successful in his action and may he be condemned by the three Holy Councils, may he receive the lot of Judas and be liable for our sins. And if some Muslim lord [tachik awag] should come and attempt to seize, may he be apitar [rejected, separated from?] by his Muhammad and may a thousand thousand nalat' [Ar., read lanat, curses] from his law be upon him, and may he be forsaken by, and blackfaced before, his God.'

50 These events receive extended treatment in Armenian historical tradition: see T'ovma Artsruni I 885: I 22.I-200.32 (book III, chs. I-I3).

5 I Garsoïan I996. 


\section{BIBLIO GR A PHY}

Adontz, N. (I970), Armenia in the Period of Justinian, ed. and trans. N. G. Garsoïan, Lisbon: Calouste Gulbenkian Foundation.

Bakhos, C. and Shayegan, M. R. (eds) (2010), The Talmud in its Iranian context, Tübingen: Mohr Siebeck.

Charanis, P. (I959), 'Ethnic Changes in Seventh-Century Byzantium', Dumbarton Oaks Papers, I3, pp. 23-44.

Garsoïan, N. G. (I985), Armenia between Byzantium and the Sasanians, London: Variorum.

Garsoïan, N. G. (1989), The Epic Histories (Buzandaran Patmut'iwnk'), Cambridge: Harvard University Press.

Garsoïan, N. G. (I 996), 'The Two Voices of Armenian Mediaeval Historiography: The Iranian Index', Studia Iranica, 25, pp.7-43.

Garsoïan, N. G. (I999a), L'Église arménienne et le grand schisme d'Orient, CSCO vol. 574, t. Ioo, Louvain: Peeters.

Garsoïan, N. G. (I999b), 'The Problem of Armenian Integration into the Byzantine Empire', in H. Ahrweiler and A. E. Laiou (eds), Studies on the Internal Diaspora of the Byzantine Empire, Cambridge: Harvard University Press, pp. 53-I 24 .

Garsoïan, N. G. (2009), 'Armenian Sources on Sasanian Administration', Res Orientales, I 8, pp.90-I I 4 .

Girk' T'tt'ots' (I90I), ed. Y. Izmireants', Tiflis: T. Rawtineants' and M. Sharadzē. (Partial trans. in Garsoïan I999a, pp.4II-583.)

Greenwood, T. W. (2004), 'A Corpus of Early Medieval Armenian Inscriptions', Dumbarton Oaks Papers, 58, pp. 27-9I.

Greenwood, T. W. (2008), 'Armenian Neighbours (600-1045)', in J. Shepard (ed.), The Cambridge History of the Byzantine Empire c. 500-I492, Cambridge: Cambridge University Press, pp.333-64.

Humfress, C. (2005), 'Law and Legal Practice in the Age of Justinian', in M. Maas (ed.), The Cambridge Companion to the Age of Justinian, Cambridge: Cambridge University Press, pp. I6I-84.

Łazar P'arpets'i (I904), Patmut'iwn Hayots' ew T'utt' à Vahan Mamikonean, eds. G. Tēr-Mkrtch'ean and S. Malxasean, Tiflis: Mnatsakan Martiroseants'. (Reprinted I985, Delmar: Caravan Books.)

Maas, M. (I986), 'Roman History and Christian Ideology in Justinianic Reform Legislation', Dumbarton Oaks Papers, 40, pp. I7-3 I.

Maas, M. (I992), John Lydus and the Roman Past: Antiquarianism and Politics in the Age of Justinian, London and New York: Routledge.

Maas, M. (2010), Readings in Late Antiquity: A Sourcebook, London and New York: Routledge.

Macuch, M. (2003), 'Zoroastrian Principles and the Structure of Kinship in Sasanian Iran', in C. G. Cereti, M. Maggi and E. Provasi (eds), Religious Themes and Texts of Pre-Islamic Iran and Central Asia: Studies in Honour of Professor Gherardo Gnoli on the Occasion of his 65 th Birthday on 6 December 2002, Beiträge zur Iranistik 24, Wiesbaden: Reichert, pp. $23 \mathrm{I}-46$.

Macuch, M. (2004), 'Pious Foundations in Byzantine and Sasanian Law', in G. Gnoli (ed.), La Persia e Bisanzio: Convegno internazionale, Roma, I4-I8 
ottobre 2002, Atti dei convegni Lincei 20I, Rome: Accademia nazionale dei Lincei, pp. I 8 I-96.

Macuch, M. (20II), 'Judicial and Legal Systems. iii: Sasanian Legal System', in Encyclopæedia Iranica, I 5 , New York: Encyclopædia Iranica Foundation, pp. I 8 I -96 .

Macuch, M. (20I4), 'Jewish Jurisdiction Within the Framework of the Sasanian Legal System', in U. Gabbay and S. Secunda (eds), Encounters by the Rivers of Babylon: Scholarly Conversations Between Jews, Iranians and Babylonians in Antiquity, Tübingen: Mohr Siebeck, pp. I47-6o.

Mahé, J.-P. and Thomson, R. W. (I997), From Byzantium to Iran: Armenian Studies in Honour of Nina G. Garsoïan, Atlanta: Scholars Press.

Movsēs Kałankatuats'i (I983), Patmut'iwn Atuanits' Ashxarhi, ed. V. Arakelyan, Erevan: Haykakan SSH GA Hratarakch'ut'yun.

Payne, R. E. (2015), A State of Mixture: Christians, Zoroastrians, and Iranian Political Culture in Late Antiquity, Los Angeles: University of California Press.

Perikhanian, A. (I997), The Book of a Thousand Judgements (A Sasanian LawBook), trans. N. G. Garsoïan, Costa Mesa: Mazda.

Sebēos (I979), Patmutiwn Sebēosi, ed. G. V. Abgaryan, Erevan: Haykakan SSH Gitut'yunneri Akademiayi Hratarakch'ut'yun.

Step'anos Orbelean (I 86I), Patmut'iwn tann Sisakan, ed. N. O. Ėmin, Moscow: Tparani Lazarean chemarani arewelean lezuats'.

Step'anos Siwnets'i (I970), Meknut'iwn k'erakanin, in N. Adontz (ed.), Denys de Thrace et les commentateurs arméniens, Louvain: Bibliothèque arménienne de la Fondation Calouste Gulbenkian: Imprimerie Orientaliste.

Thomson, R. W. (trans.) (I99I), The History of Łazar P'arpec'i, Atlanta: Scholars Press.

Thomson, R. W. and Howard-Johnston, J. (trans. and ed.) (I999), The Armenian History Attributed to Sebeos, TTH 3 I, 2 vols, Liverpool: Liverpool University Press.

T'ovma Artsruni (I887), Patmut'iwn tann Arcruneats', ed. K'. Patkanean, St Petersburg: Tparan N. Skoroxodov. (Reprinted I99I, Delmar: Caravan Books.) 